BioScience, 2005, v.55, n.2, pp.155-167.

ISSN: 0006-3568

doi: 10.1641/0006-3568(2005)055[0155:LLAFWE]2.0.CO;2

http://www.aibs.org/bioscience/current_issue.html

http://www.bioone.org/doi/pdf/10.1641/0006-

3568(2005)055\%5B0155\%3ALLAFWE\%5D2.0.CO\%3B2

(C) 2005 American Institute of Biological Sciences. 


\title{
Linking Landscapes and Food Webs: Effects of Omnivorous Fish and Watersheds on Reservoir Ecosystems
}

\author{
MICHAEL J. VANNI, KRISTIN K. AREND, MARY T. BREMIGAN, DAVID B. BUNNELL, JAMES E. GARVEY, \\ MARÍA J. GONZÁLEZ, WILLIAM H. RENWICK, PATRICIA A. SORANNO, AND ROY A. STEIN
}

\begin{abstract}
Ecologists increasingly recognize the need to understand how landscapes and food webs interact. Reservoir ecosystems are heavily subsidized by nutrients and detritus from surrounding watersheds, and often contain abundant populations of gizzard shad, an omnivorous fish that consumes plankton and detritus. Gizzard shad link terrestrial landscapes and pelagic reservoir food webs by consuming detritus, translocating nutrients from sediment detritus to the water column, and consuming zooplankton. The abundance of gizzard shad increases with watershed agriculturalization, most likely through a variety of mechanisms operating on larval and adult life stages. Gizzard shad have myriad effects on reservoirs, including impacts on nutrients, phytoplankton, zooplankton, and fish, and many of their effects vary with ecosystem productivity (i.e., watershed land use). Interactive feedbacks among watersheds, gizzard shad populations, and reservoir food webs operate to maintain dominance of gizzard shad in highly productive systems. Thus, effective stewardship of reservoir ecosystems must incorporate both watershed and food-web perspectives.
\end{abstract}

Keywords: watershed, reservoir, food web, detritus, landscape ecology

cologists increasingly recognize the need to

understand how food webs and landscapes are linked (Polis et al. 2004). Fluxes of organisms, detritus, nutrients, and other materials across landscapes can strongly affect recipient food webs. For example, many studies show that subsidies of plant-available nutrients stimulate primary production and cause changes in species composition of plants as well as organisms at higher trophic levels (Carpenter et al. 1998). Inputs of detritus or organisms to a food web are less studied but may have complex effects that depend on the trophic position at which these subsidies enter a food web. For example, inputs of detritus can increase the abundance of detritivores in recipient food webs, which can thus increase their effects on other species through various direct and indirect pathways (Moore et al. 2004, Polis et al. 2004). Although most ecosystems are subsidized, the consequences of subsidies remain unknown for most subsidies and for most food webs.

Freshwater ecosystems are highly subsidized because their downhill position relative to their terrestrial watersheds facilitates movement of materials toward them. Inputs of dissolved nutrients and detritus to aquatic ecosystems can regulate primary productivity, food web interactions, and energy flow (e.g.) Carpenter et al. 1998, Wallace et al. 1999, Pace et al. 2004). Reservoirs (lakes formed through impoundment of rivers by dam construction) are the dominant lake type in
North America at latitudes below $42^{\circ}$ north, and are highly subsidized ecosystems (Thornton 1990). Because they have relatively large watersheds, reservoirs receive substantial inputs of nutrients and detritus from streams that drain terrestrial landscapes. Nutrient and detritus subsidies are particularly large to reservoirs in agricultural landscapes, where many eastern US reservoirs reside, because of the use of fertilizers and high rates of soil erosion (Carpenter et al. 1998). There is evidence that detritus subsidies are important in these reservoir ecosystems. For example, reservoir fish productivity often cannot be supported entirely by in-lake primary production but rather must be subsidized largely by inputs of detritus (Adams et al. 1983).

Michael J. Vanni (e-mail: vannimj@po.muohio.edu) and María J. González are with the Department of Zoology, and William H. Renwick is with the Department of Geography, at Miami University, Oxford, OH 45056. Kristin K. Arend is a graduate student at Cornell University, Ithaca, NY 14853. Mary T. Bremigan and Patricia A. Soranno work at the Department of Fisheries and Wildlife, Michigan State University, East Lansing, MI 48824. David B. Bunnel is with the US Geological Survey, Great Lakes Science Center, Ann Arbor, MI 48105. James E. Garvey works at the Fisheries and Illinois Aquaculture Center, Department of Zoology, Southern Illinois University, Carbondale, IL 62901. Roy A. Stein works at the Aquatic Ecology Laboratory, Department of Evolution, Ecology and Organismal Biology, The Ohio State University, Columbus, OH 43212. ( 2005 American Institute of Biological Sciences. 


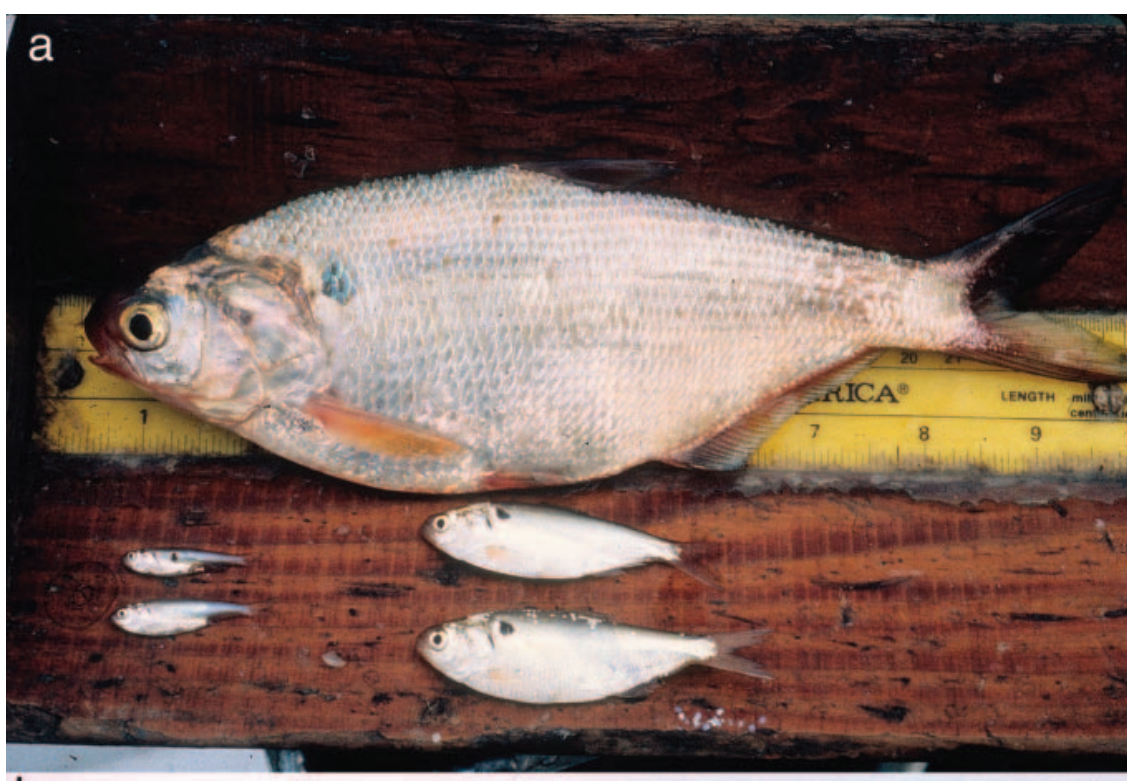

b

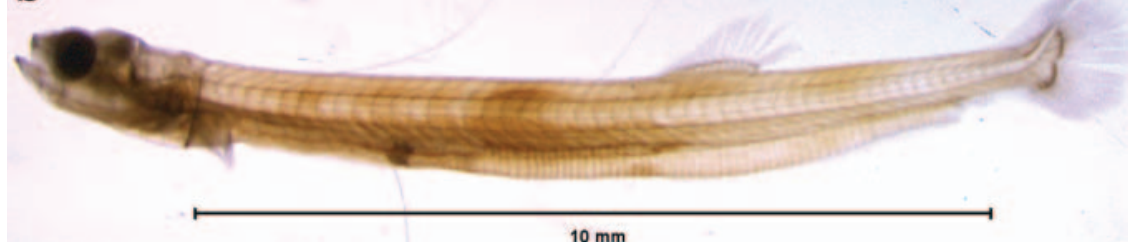

Figure 1. Gizzard shad from Ohio reservoirs. (a) The large individual is an adult, several years old. The intermediate-sized fish are juveniles just over 1 year old, while the small individuals are young-of-year juveniles, a few months old. Photograph: Russell Wright, Auburn University. (b) A larval gizzard shad. Photograph: Alberto Pilati, Miami University.

Perhaps as a consequence of detritus subsidies, fish assemblages of many reservoirs of eastern North America are dominated by gizzard shad (Dorosoma cepedianum; figure 1), an omnivore that often consumes considerable amounts of detritus. This species can strongly affect many components of aquatic ecosystems, including other fish species, zooplankton, phytoplankton, and nutrients (Drenner et al. 1986, 1996, DeVries and Stein 1992, Stein et al. 1995, Schaus et al. 1997, Schaus and Vanni 2000, Watson et al. 2003). The notion that gizzard shad can regulate reservoir ecosystems has important implications for the stewardship of these ecosystems. Because gizzard shad can depress the abundance of economically important sport fish in some instances, their impacts have implications for fisheries management (Stein et al. 1995). Furthermore, because gizzard shad often promote growth of phytoplankton via both nutrient cycling and trophic interactions (Schaus et al. 1997, Schaus and Vanni 2000, Aday et al. 2003), they may negatively affect water quality. Gizzard shad abundance seems to be greatly subsidized by delivery of allochthonous materials from watersheds, so this species may serve as a critical link between surrounding landscapes and reservoir food webs. Thus, we argue here that a landscape perspective is necessary for elucidating the causes and consequences of gizzard shad dominance in reservoirs, and thus for understanding and managing these important ecosystems.

In this article we synthesize evidence showing that the food webs of reservoirs in eastern North America are controlled by the combined effects of subsidies from watersheds and the activities of gizzard shad, and explore how these interactions vary with ecosystem productivity. After a brief description of gizzard shad biology, we discuss how watershed subsidies drive gizzard shad abundance, how gizzard shad affect reservoir ecosystems, and how these effects vary with watershed subsidies (and hence ecosystem productivity). We conclude by discussing some explicit examples of feedbacks among watersheds, gizzard shad, and reservoir ecosystem function, and the implications of these interactive effects for reservoir management.

\section{Biology of gizzard shad}

Gizzard shad are members of the herring family (Clupeidae). Although there are many species of shad in the herring family, only the gizzard shad relies on sediment detritus as a food source. Gizzard shad are native to eastern North America and are geographically widespread (figure 2), inhabiting natural lakes, rivers, and reservoirs.

Gizzard shad are omnivores, and their diets vary with life-history stage (figure 3 ). Larvae (fish < approximately 20 millimeters [ $\mathrm{mm}$ ] in length) are obligate zooplanktivores, consuming rotifers, copepods, and cladocerans (Bremigan and Stein 1994, Miranda and $\mathrm{Gu}$ 1998). Young-of-year (YOY) juveniles (fish approximately 25 to $30 \mathrm{~mm}$ in length) develop morphological features, including a subterminal mouth, muscular gizzard, and elongated intestinal tract that allow them to feed on sediment detritus, an abundant but nutritionally poor food source (Mundahl and Wissing 1987). The feeding mode of gizzard shad also changes at this time. Whereas larvae visually feed on individual prey items, juveniles and adults are pump-filter feeders; in this latter mode they can essentially vacuum-filter organic matter from sediments (Drenner et al. 1984). Thus, as YOY gizzard shad become juveniles, their diets can broaden from zooplankton to detritus as well, with the actual diets of postlarval gizzard shad depending somewhat on the relative abundance of potential foods. When large zooplankton such as Daphnia are available, gizzard shad may consume considerable amounts of zooplankton throughout their entire lives. However, in many ecosystems and especially in reservoirs, diets of juvenile and adult gizzard shad consist nearly entirely of sediment detritus (Mundahl and Wissing 1987, Schaus et al. 2002). Because of the higher caloric and nutrient content of zooplankton, it is presumed that gizzard shad will benefit 
from zooplankton availability. However, the negative effects of a lack of zooplanktivory may be somewhat buffered by gizzard shad's ability to selectively feed on relatively high-quality detritus (Mundahl and Wissing 1987), although the behavioral or morphological means by which they do so is not clear. Reliance on sediment detritus is a relatively unusual habit among freshwater temperate fish, although it is fairly common among freshwater tropical fish (Lowe-McConnell 1987).

As is typical of clupeids, gizzard shad are highly fecund, a trait that undoubtedly contributes to their ability to establish and increase rapidly in newly colonized habitats (Stein et al. 1995). Studies in Alabama, Ohio, and Missouri reservoirs, and natural lakes in Florida, reveal that gizzard shad abundance increases strongly with ecosystem productivity, more so than that of other fish species (Bachmann et al. 1996, DiCenzo et al. 1996, Michaletz 1997, Bremigan and Stein 2001). Gizzard shad are scarce in unproductive (oligotrophic) ecosystems, common in moderately productive (mesotrophic) ecosystems, and very abundant under highly productive (eutrophic and hypereutrophic) conditions. In highly productive systems, they are often the most abundant fish in terms of biomass (Miranda 1983, Bachmann et al. 1996). Identifying the mechanisms responsible for gizzard shad dominance is crucial, for these mechanisms underlie the variable effects of shad on reservoir ecosystems.

Omnivory or facultative detritivory, high fecundity, and rapid growth rates that allow YOY gizzard shad to escape predation by gape-limited piscivores may help explain why gizzard shad become so abundant in some ecosystems (Stein et al. 1995). In the following section we discuss mechanisms that may explain why life-history characteristics of gizzard shad (e.g., facultative detritivory, high fecundity, and rapid growth rates) and watershed features (e.g., land use and watershed size) together allow gizzard shad abundance to increase so strongly with ecosystem productivity.

\section{Gizzard shad dominance in relation to watershed subsidies and reservoir productivity}

Why are reservoir fish assemblages increasingly dominated by gizzard shad as productivity increases? Most likely, the answer to this question lies in the linkages among various aspects of reservoir productivity (which are ultimately driven by watershed subsidies) and gizzard shad life-history characteristics. In particular, gizzard shad are probably affected by the timing, amount, and composition of nutrient and detritus subsidies, all of which vary to some extent with watershed characteristics. These watershed influences are complex, because each life-history stage (larva, juvenile, and adult) of gizzard shad will be affected differently by watershed subsidies.

Watershed land use and productivity. Reservoirs of eastern North America reside in watersheds that span a gradient of land use. This is illustrated by our study reservoirs and watersheds in Ohio, which lie along a gradient from forestdominated to agriculture-dominated land use (figure 4). Across these reservoirs, indicators of ecosystem productivity (e.g., total phosphorus concentration, phytoplankton biomass and production) are correlated with the extent of agricultural land use in their watersheds (figure 5a, 5b, 5c). More specifically, land use appears to set an upper bound to productivity, below which there is considerable variation (figure $5 \mathrm{a}, 5 \mathrm{~b}$, 5c); other factors, such as the type of agriculture (e.g., crops versus animal production) and the size of the watershed relative to reservoir volume, also may influence productivity (Knoll et al. 2003).

\section{Response of detritivorous life stages to watershed subsi-}

dies. Detritivorous gizzard shad (juveniles and adults) may respond directly to watershed inputs of particulate allochthonous detritus that are not available to traditional pelagic food web pathways (i.e., pathways through primary producers). Incoming detritus particles quickly settle out, and so their nutrients generally are not available to phytoplankton. Rather, these particulate nutrients become part of the detritus pool in reservoir sediments, where they can serve as food for juvenile and adult gizzard shad. An additional detrital source results from phytoplankton that sink to the reservoir sediments without being consumed by zooplank- 


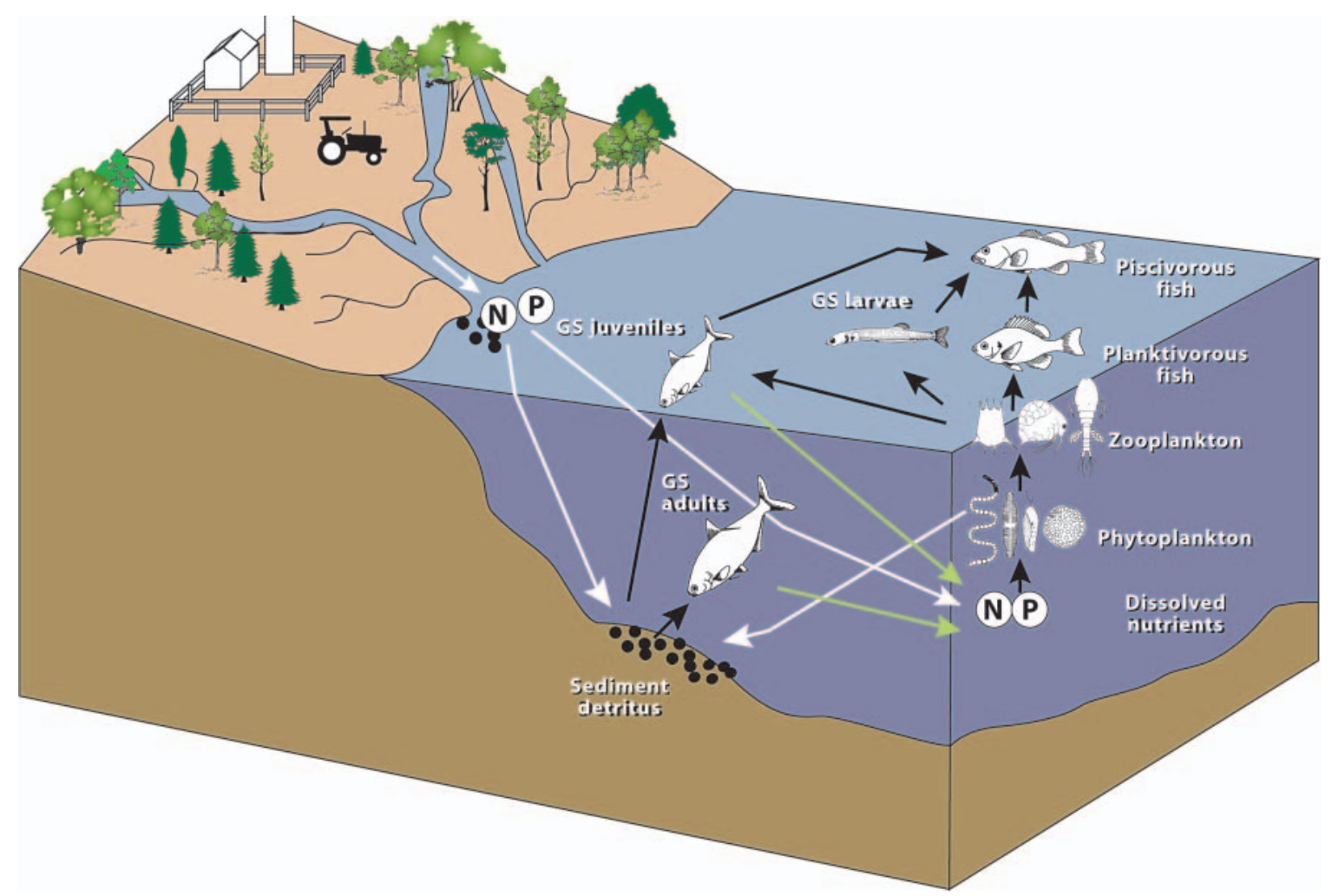

Figure 3. Gizzard shad link watersheds and the pelagic grazing food chain in reservoirs. The watershed is the ultimate regulator of reservoir food webs by providing nutrients directly to phytoplankton and detritus that subsidizes gizzard shad populations; sedimentation of phytoplankton also provides a detrital resource for gizzard shad. These fluxes of materials across ecosystem or habitat boundaries are indicated by white arrows. Gizzard shad juveniles and adults provide nutrients to phytoplankton through nutrient translocation (green arrows), thereby further stimulating primary production. Gizzard shad larvae and juveniles function as zooplanktivores, thereby reducing resources for other zooplanktivorous fish, and serve as prey for piscivorous fish. These and other feeding relationships are represented by black arrows. Organisms and ecosystems are not drawn to scale. Abbreviations: GS, gizzard shad; N, nitrogen; $P$, phosphorus.

ton herbivores; this flux can represent a substantial fraction of primary production. Because phytoplankton production increases with watershed inputs of dissolved nutrients, both the input of allochthonous particulate detritus and the flux of phytoplankton to the sediment detritus pool increase when watersheds are converted to agriculture (figure 3 ). It is not known to what extent gizzard shad abundance is subsidized by direct allochthonous inputs of detritus versus increased phytodetritus production, but the carbon-to-nitrogen ratios of detritus consumed by gizzard shad suggest that at least some material is derived from terrestrial sources (Mundahl and Wissing 1987). Whether they assimilate mainly allochthonous or autochthonous material, reliance on detritus gives gizzard shad a potentially large advantage over other fishes, because few other species can utilize this food resource. Thus, increased detrital production can provide a food subsidy for adult and juvenile gizzard shad, thereby increasing survival (via reduced starvation risk), promoting high fecundity, and ultimately resulting in high population density. Data from Ohio reservoirs support this scenario; the number and biomass of juvenile and adult gizzard shad increases with the extent of agriculture in watersheds (figure $5 \mathrm{e}$, $5 f)$.

Response of zooplanktivorous life stages to watershed subsidies. In contrast to detritivorous life stages, larval gizzard shad (and zooplanktivorous juveniles) may respond primarily to inputs of dissolved inorganic nutrients, which stimulate planktonic production (figure 3). Both the production of larvae (hatch) and the survival of larval gizzard shad increase with reservoir productivity (figure 5g, 5h, 5i). In relatively lowproductivity Ohio reservoirs, low hatch abundance limits recruitment. Thus, even if larval survival is unusually high, relatively few juveniles are produced because so few larvae are born (Bremigan and Stein 2001). In contrast, hatch rates are consistently high in very productive reservoirs, and variable survival of larval gizzard shad appears to drive variation in year-class strength. Higher hatch rates in productive reservoirs are most likely due to the presence of a greater number of spawning adults, but higher adult fecundity or egg quality also 
may contribute. Growth rate of individual YOY gizzard shad does not clearly correlate with reservoir productivity across mesotrophic to hypereutrophic conditions (DiCenzo et al. 1996, Michaletz 1997), although in at least some years, YOY gizzard shad in hypereutrophic reservoirs grow to a larger size than those in eutrophic reservoirs (Bremigan and Stein 1999). Rapid growth may enhance firstyear survival of gizzard shad by decreasing their predation risk to gape-limited piscivores such as bass (predation risk may also be lower in highly productive, turbid reservoirs because of decreased detection by visual predators; see below).

The positive relationship between reservoir productivity and larval gizzard shad success is probably mediated by zooplankton abundance, production, and community or size structure. Increased phytoplankton production may enhance zooplankton production, and this may benefit zooplanktivorous larval gizzard shad. In general, the abundance of small zooplankton increases with increasing productivity (Bunnell et al. 2003), indicating that highly productive systems may support greater larval survival, and hence the formation of strong year classes.

Experiments and field data document that both abundance and size composition of zooplankton play a role in determining larval gizzard shad success. In particular, rotifers are an important prey item for larvae less than $10 \mathrm{~mm}$ long, but can also be consumed in high proportions by larger larvae (Miranda and $\mathrm{Gu}$ 1998). For larvae more than $10 \mathrm{~mm}$ long, high densities of copepod nauplii and other small zooplankton $(<0.4 \mathrm{~mm})$ promote larval gizzard shad foraging success and survival (Bremigan and Stein 1994, 1999, 2001). Because larval gizzard shad have small gapes, they can utilize small zooplankton better than other fish species. In Ohio reservoirs, the biomass of rotifers increases with productivity (i.e., agriculture in watershed), while that of larger taxa such as cladocerans and copepods decreases (figure 5d). Thus, highly productive systems may favor success of larval gizzard shad over larvae of other species (Bremigan and Stein 1994).

However, temporal variability in zooplankton assemblages at several scales complicates the relationship between reservoir productivity and larval survival. For example, in Ohio reservoirs, biomass of crustacean zooplankton less than 0.4 $\mathrm{mm}$ in length appears to increase with reservoir productivity in some years, but not in others (Bremigan and Stein 1999, 2001). Further, because newly hatched larval gizzard shad are quite vulnerable to starvation, their survival appears to be strongly influenced by week-to-week variation in the pro-

\section{Study watersheds}

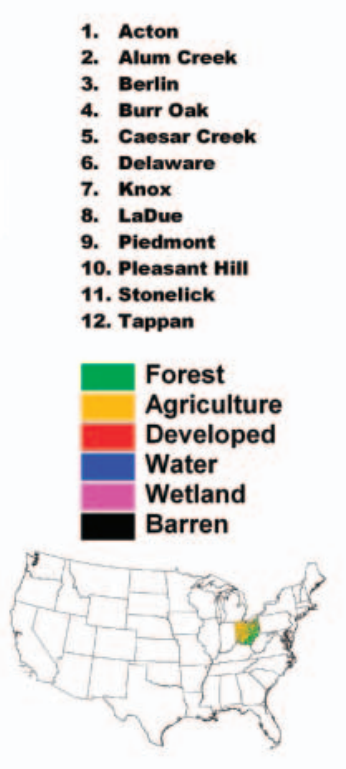

(1)

Figure 4. Land-use map of Ohio and locations of study watersheds and reservoirs. Agricultural land includes that used for animal operations as well as crops, but the bulk of agricultural land is characterized by intensive row-crop agriculture (i.e., corn and soybeans). Developed land includes urban and suburban areas. Thick black lines delineate watershed boundaries, while study reservoirs are represented by blue areas within watersheds. Note that watersheds are very large in area relative to reservoir surface areas, and that study watersheds represent a gradient of land use from forest to agriculture.

duction of small zooplankton during the 4- to 6-week period when most larval gizzard shad hatch (Bremigan and Stein 1999). Thus, understanding why the abundance, size structure, and species composition of zooplankton vary across reservoirs and over time is important for predicting larval gizzard shad success.

Interactions among watershed subsidies, reservoir features, and gizzard shad life history. Watershed and reservoir features can ultimately drive the population dynamics of gizzard shad by mediating the timing and availability of nutrient and detritus inputs. At broad spatial scales, the magnitudes of nutrient and detritus subsidies depend on land use (e. g., the extent of urbanization or agriculture; figure 5), geology, precipitation, and the size of the watershed (Puckett 1995). At finer scales, subsidy magnitudes are also a function of subwatershed sizes, slope, spatial patterns of land use, and the extent and integrity of riparian zones (Osborne and Wiley 1988, Soranno et al. 1996). The proportions of nutrients exported in particulate and dissolved forms also differ among watersheds, and this may determine which life stages of gizzard shad are affected by watershed subsidies. For example, agricultural watersheds export greater quantities of particulate matter than do forested and urban watersheds, perhaps promoting the success of detritivorous life stages of gizzard shad that can consume these particles. 
Spatial features of reservoirs are also likely to be important in determining gizzard shad dominance. Reservoirs with extensive well-oxygenated, shallow areas should support the
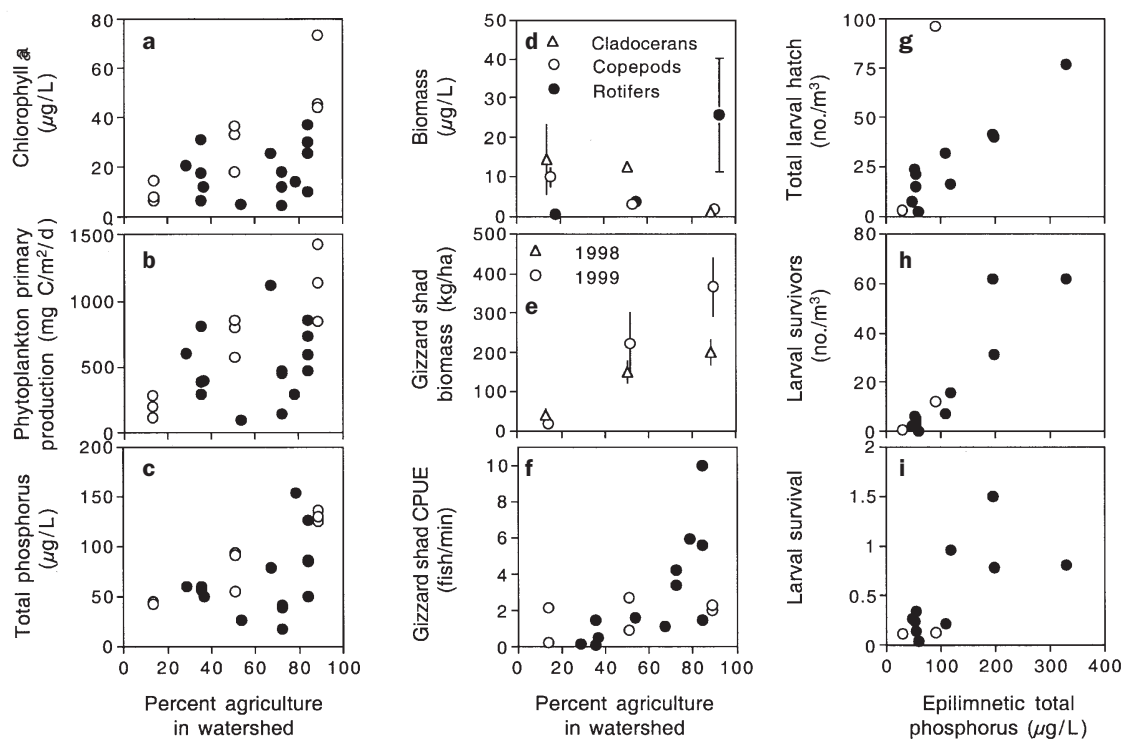

Figure 5. Correlations between watershed land use, productivity indicators, and gizzard shad abundance in Ohio reservoirs. Relationships between the percentage of watershed land area comprising agriculture and (a) phytoplankton biomass (chlorophyll a), (b) primary production of phytoplankton, and (c) total phosphorus concentration were derived from Knoll and colleagues (2003) and represent data collected 1998-2000 from the 12 reservoirs shown in figure 4. Each point represents a lake-year mean (some reservoirs were sampled multiple years). Open symbols represent three intensively sampled reservoirs (Acton, Burr Oak, and Pleasant Hill). (d) The relationship between the percentage of agriculture in the watershed and the biomass of the three major zooplankton groups was derived from data collected 1998-2000 from the three intensively sampled reservoirs (Acton, Burr Oak, and Pleasant Hill). Each point represents a mean ( \pm standard error [SE]) of all sample dates. (e) The relationship between the percentage of agriculture in the watershed and inshore adult and juvenile (i.e., nonlarval) gizzard shad biomass was quantified in the three intensively sampled reservoirs (Acton, Burr Oak, and Pleasant Hill) using the quadrat rotenone technique described by Schaus and colleagues (1997). Each data point represents a mean ( \pm SE) of five quadrats sampled within a one-week period in late summer 1998 or 1999. (f) The relationship between the percentage of agriculture in the watershed and the relative abundance (catch per unit effort, or CPUE) of adult and juvenile (i.e., nonlarval) gizzard shad was derived from 1998 and 1999 data from the same 12 reservoirs. Data were obtained by electrofishing for a standardized time period in several habitats in each lake. Each point represents a lake-year mean (some reservoirs were sampled multiple years). Open symbols represent three intensively sampled reservoirs (Acton, Burr Oak, and Pleasant Hill). The relationship between the total phosphorus in the epilimnion of reservoirs (an indicator of productivity) and ( $\mathrm{g}$ ) gizzard shad larval hatch, (h) larval survivors (larvae surviving to $15 \mathrm{~mm}$ total length), and (i) larval survival rate in 12 Ohio reservoirs was derived from Bremigan and Stein (2001). Note that some of these reservoirs are different from those represented in panels $a-c$ and $f$. Specifically, panels $g-i$ share six reservoirs in common with panels $a-c$ and $f$. Open symbols represent two of the intensively sampled reservoirs (Burr Oak and Pleasant Hill). reservoirs. In addition, smaller reservoirs will usually receive more nutrient inputs than large reservoirs (per unit reservoir area or volume) because of a higher ratio of watershed area to lake area (similar to how marine-derived subsidies to oceanic islands increase as the island perimeter-to-area ratio increases; Polis et al. 2004). In contrast, relatively deep reservoirs that contain large volumes of anoxic hypolimnetic water should have the lowest biomass of shad. Thus, we expect gizzard shad to dominate in reservoirs that are well oxygenated, shallow, and small in surface area relative to their watersheds, and that reside in watersheds dominated by agricultural land use, with little forested riparian cover.

\section{Impacts of gizzard shad on reser- voir ecosystems along a gradient of productivity}

Gizzard shad can strongly influence various components of reservoir ecosystems, including nutrients, phytoplankton, zooplankton, and fish. In this section we discuss these effects and explore how they may vary with overall reservoir productivity.

Gizzard shad effects on nutrients and phytoplankton. Gizzard shad translocate nutrients from benthic to pelagic habitats by ingesting particulate nutrients in sediment detritus and excreting some of these nutrients into the water column in dissolved inorganic forms (figure 3; Schaus et al. 1997, Schaus and Vanni 2000, Vanni and Headworth 2004). Nutrient translocation can directly increase phytoplankton biomass and thus contribute to algal blooms and eutrophication.

Nutrient translocation by gizzard shad can be a substantial source of nutrients even in productive reservoirs receiving large quantities of dissolved inorganic nutrients from agricultural watersheds (Schaus et al. 1997, Vanni et al. 2001). Within a lake, the relative importance of nutrient translocation by gizzard shad varies temporally, depending both on annual differences in shad abundance 
and on seasonal variation in precipitation, which drives allochthonous nutrient inputs by controlling surface runoff to streams (Vanni et al. 2001, Schaus et al. 2002). In Acton Lake, a highly productive reservoir with abundant gizzard shad and an agriculture-dominated watershed, gizzard shad provide more dissolved inorganic phosphorus to the water column than does the entire watershed when streams are at or near baseflow conditions; however, during storms, nutrient inputs from the watershed can be orders of magnitude above those provided by gizzard shad (figure 6a). Thus, within a single reservoir, the relative importance of gizzard shad in providing available nutrients (compared to the watershed) depends on the relative frequency of storms, as well as gizzard shad abundance. Among reservoirs, the watershed features discussed above, such as land use, geology, and spatial patterns, also will mediate the relative importance of gizzard shad and watersheds as nutrient sources.

As omnivores, gizzard shad sometimes consume phytoplankton, but several experimental studies demonstrate enhancement of total phytoplankton biomass by gizzard shad (Drenner et al. 1986, 1996, Schaus and Vanni 2000, Watson et al. 2003). In addition, a recent comparison of 20 Illinois reservoirs showed that phytoplankton biomass was approximately 1.7 times higher in reservoirs with gizzard shad than in those without gizzard shad (Aday et al. 2003). Enhancement of phytoplankton by gizzard shad can occur via a trophic cascade (i.e., relaxation of herbivory via depression of zooplankton biomass; Carpenter et al. 1985), nutrient translocation, or both. An experiment in Acton Lake showed that enhancement of phytoplankton by gizzard shad occurred only when shad fed on sediments (figure $6 b$ ), strongly suggesting that the stimulatory effects on phytoplankton were mediated via nutrient translocation (Schaus and Vanni 2000). However, other enclosure studies, without sediments present, reveal enhanced phytoplankton biomass in conjunction with depression of zooplankton biomass by shad (Drenner et al. 1986, 1996, Watson et al. 2003). Thus, the positive effects of gizzard shad on phytoplankton may occur through
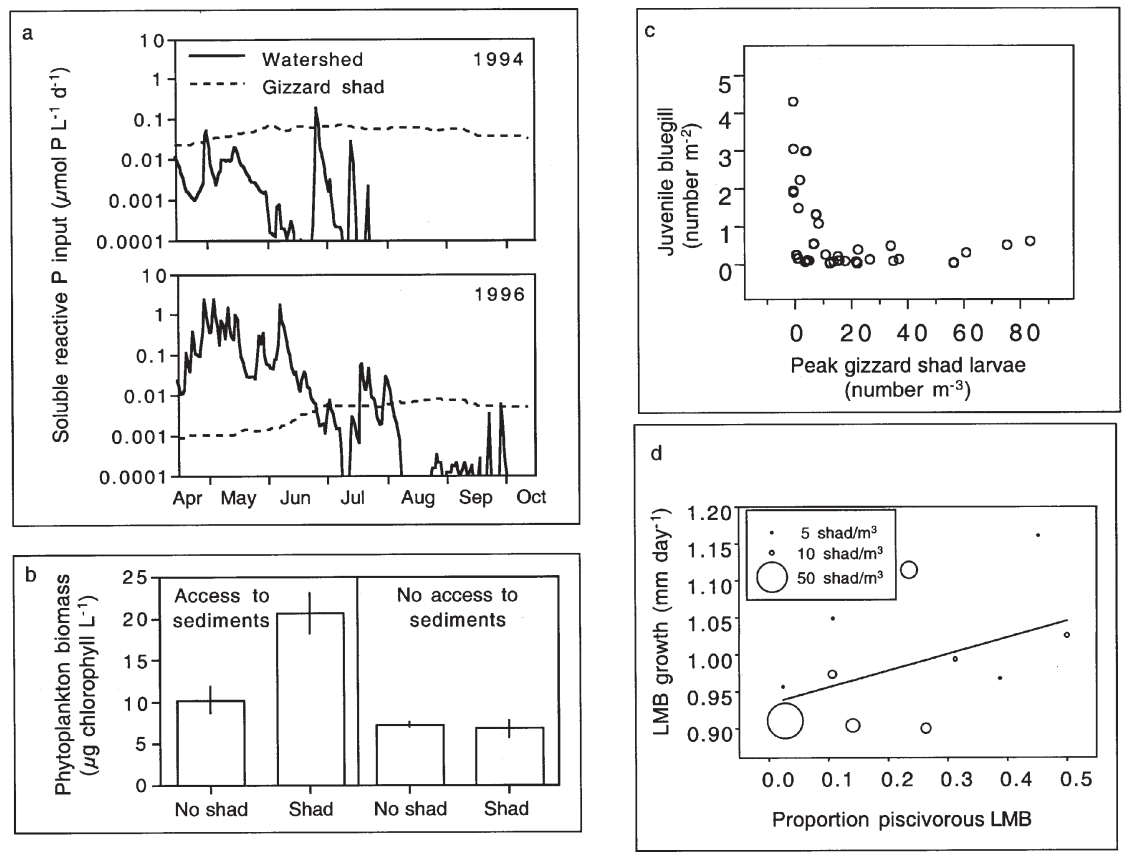

Figure 6. Effects of gizzard shad on various reservoir ecosystem components. (a) Inputs of soluble reactive phosphorus (P, per liter of lake water) from the entire watershed, and inputs via nutrient translocation by the gizzard shad population in Acton Lake. 1994 was a dry year with low runoff and very high gizzard shad biomass; 1996 was a wet year with high runoff and very low gizzard shad biomass. Data are derived from Schaus and colleagues $(1997,2002)$ and Vanni and colleagues (2001). Spikes of $P$ input from the watershed represent individual storms. During most storms, the watershed greatly exceeds the gizzard shad population as a P source (note log scale); between storms, gizzard shad provide more $P$ than the watershed. (b) Effects of gizzard shad on phytoplankton biomass (chlorophyll a, mean + standard error) in an enclosure experiment in Acton Lake conducted in 1994, modified from Schaus and Vanni (2000). Half the enclosures contained screens that prevented shad from feeding on sediments, while half did not have screens, allowing shad access to sediments. Shad stimulated phytoplankton biomass only when they had access to sediments, suggesting that their effects were due to nutrient translocation and not a trophic cascade. (c) Relationship between peak larval gizzard shad densities and inshore juvenile bluegill densities (as estimated by seining catch per unit effort) in Ohio reservoirs. Data derive from 4 Ohio reservoirs during 1987 through 1994 and an additional 10 reservoirs during 1998. Bluegill abundance reflects individuals that had interacted with shad as larvae in the open water during spring. Below a threshold of 10 shad per cubic meter, bluegill densities vary widely and independently of shad. Above this threshold, bluegill densities are consistently low, suggesting that bluegill are negatively affected by competition as larvae, and potentially by other abiotic factors that covary positively with shad. (d) Correlation between the proportion of age-0 largemouth bass (LMB) that are piscivorous and mean LMB growth rate during summer 1998 in 11 Ohio reservoirs. Size of symbols represents the relative peak density of gizzard shad larvae in each system. Growth rates of LMB were estimated by using otoliths to determine age in days. Piscivory was positively correlated with $L M B$ growth $(\mathrm{r}=0.47)$, suggesting that growth is enhanced by the bass's ability to consume fish. The lowest growth rates and degree of piscivory occurred in lakes with the highest shad densities. 
nutrient translocation and trophic cascades, and seem to outweigh their potential negative effects through direct consumption of phytoplankton.

Gizzard shad excrete nutrients at a low nitrogen-tophosphorus (N:P) ratio (Schaus et al. 1997), especially in comparison with the ratio at which nutrients are delivered from agricultural watersheds (Vanni et al. 2001). Excretion by shad could promote dominance of cyanobacteria (blue-green algae), which thrive at low N:P ratios. However, although several experiments reveal that gizzard shad stimulate cyanobacteria, in general the relative enhancement of cyanobacteria is not greater than that of other phytoplankton groups (Drenner et al. 1986, Schaus and Vanni 2000).

How might the importance and consequences of nutrient translocation by gizzard shad vary with reservoir productivity? Nutrient flux through gizzard shad should increase with reservoir productivity simply because gizzard shad abundance increases greatly along this gradient. However, productive reservoirs also receive greater nutrient inputs (per reservoir area) from their watersheds than do unproductive reservoirs. Therefore, it is not immediately clear how the relative importance of nutrient translocation by gizzard shad (i.e., versus the importance of allochthonous nutrient input) varies along the productivity gradient. A model developed by Vanni and Headworth (2004) predicts that the proportion of total phytoplankton production supported by nutrient translocation by gizzard shad increases with reservoir productivity. This suggests that, even though nutrient inputs from watersheds increase with increasing agriculture, the nutrient translocation effects of gizzard shad increase relatively more. This prediction is currently being tested in Ohio reservoirs.

Gizzard shad effects on zooplankton. Experimental and empirical studies demonstrate that larval, juvenile, and adult gizzard shad can deplete zooplankton biomass, especially that of crustaceans (DeVries and Stein 1992, Dettmers and Stein 1996). Given that gizzard shad abundance increases with productivity, the total consumptive demand by gizzard shad should also increase with productivity. However, the extent to which zooplankton can persist should also depend on zooplankton production. For example, zooplankton persistence in the face of predation by juvenile gizzard shad was positively related to zooplankton production in experimental enclosures (Dettmers and Stein 1996). Therefore, if zooplankton production increases with reservoir productivity, highly productive reservoirs may be buffered to some degree from negative effects of shad on zooplankton (Dettmers and Stein 1996). Contrary to these expectations, Bremigan and Stein (2001) found no pattern relating crustacean zooplankton production to reservoir productivity. In addition, Drenner and colleagues (1996) found that an equal biomass of gizzard shad had greater effects on zooplankton biomass under high-productivity conditions than under low productivity.

Effects of gizzard shad larvae on zooplankton species composition are not well understood. Experimental work on the effects of gizzard shad on zooplankton has focused on crustaceans. Effects of shad on rotifers are less studied, even though they are often the dominant zooplankton group in terms of species richness and abundance in productive reservoirs (Pollard et al. 1998, Bunnell et al. 2003). Gizzard shad larvae prey heavily on rotifers and copepods (Miranda and $\mathrm{Gu}$ 1998), and copepods can be an important predator of rotifers (Williamson 1980). Thus, gizzard shad larvae can affect rotifer assemblages via direct and indirect pathways, but predicting such effects may be difficult because of this intraguild predation (sensu Polis et al. 1989) and because effects are likely to vary with ecosystem productivity.

Gizzard shad effects on planktivorous fish. Almost all fish species have larval stages that consume zooplankton, and by depressing the abundance of zooplankton, gizzard shad can reduce the growth and survival of these fish (DeVries and Stein 1992). In Ohio reservoirs, larval gizzard shad and juvenile bluegill abundances are negatively correlated (figure 6c). Effects of gizzard shad on planktivorous fish may be mediated by the degree of interspecific temporal overlap in spawning; if gizzard shad larvae hatch early, they may depress zooplankton densities before larvae of other fish species appear. For example, in a mesocosm experiment, YOY gizzard shad reduced growth of larval bluegill only when shad were stocked relatively early (Garvey and Stein 1998a). The factors influencing the relative timing of appearance of YOY gizzard shad versus other species are not well understood, but probably depend on complex relationships among reservoir temperature, inputs of water from watersheds, and adult condition. Ultimately, all of these factors are regulated by watershed-scale processes.

Gizzard shad effects on piscivorous fish. Gizzard shad can affect piscivorous fish in several ways. As mentioned above, competition with gizzard shad for zooplankton can lead to poor recruitment of zooplanktivorous fish species. This can reduce the growth of YOY stages of piscivorous fish (e.g., largemouth bass), which prey on these small zooplanktivorous fish (Garvey and Stein 1998b, Garvey et al. 1998). In addition, gizzard shad can have direct negative effects on piscivores. YOY gizzard shad can grow quite rapidly in highly productive reservoirs, perhaps because of their ability to utilize detritus. Rapid growth of YOY gizzard shad reduces their vulnerability to predation by gape-limited YOY largemouth bass, so YOY bass often grow slowly when gizzard shad dominate (e.g., Garvey and Stein 1998b), thereby reducing bass survival over their first winter (Garvey et al. 1998). In Ohio reservoirs, growth of largemouth bass tended to be lower in systems with abundant gizzard shad, where bass were less likely to be piscivorous (figure $6 \mathrm{~d}$ ). Thus by suppressing the abundance of zooplanktivorous fish and by rapidly growing to a size invulnerable to YOY bass, gizzard shad may reduce recruitment of this top predator.

However, not all effects of gizzard shad on piscivores are negative. In some cases gizzard shad provide valuable forage 
for piscivores. In fact, gizzard shad historically have been stocked in lakes and reservoirs to provide supplemental prey or predatory buffer for sportfish (e.g., largemouth bass, crappie, and bluegill), a practice that has yielded positive, equivocal, and negative results (DeVries and Stein 1990). In some cases, adult predatory fish consume gizzard shad and grow rapidly (Michaletz 1997). Similarly, in nine Alabama reservoirs ranging from mesotrophic to eutrophic, YOY largemouth bass abundance and growth increased with productivity as YOY gizzard shad abundance increased. In these reservoirs, YOY gizzard shad remained vulnerable to YOY bass throughout much of the summer (Allen et al. 1999).

Overall, the impact of YOY gizzard shad on YOY bass varies as a function of several potentially important factors, including the growth rates of YOY shad and the temporal and spatial overlap between shad and bass. We hypothesize that increases in gizzard shad abundance and density-dependent reductions in shad growth occur as productivity increases from moderate (mesotrophic) to high (eutrophic), such that YOY bass growth should increase across this range as well (Allen et al. 1999). However, in the most highly productive (hypereutrophic) systems, YOY gizzard shad grow rapidly, at least in some years, despite their high abundance. High growth rates in these hypereutrophic systems should lead to neutral or negative effects of gizzard shad on bass. In addition, variability in the effects of YOY gizzard shad on YOY bass should be greatest in highly productive reservoirs, owing to high variability in YOY shad growth rates and duration of spawning in these systems. Further, an example from five Ohio reservoirs during 3 years demonstrates the importance of spatial and temporal overlap between YOY shad and bass. In this study, gizzard shad served as important prey for YOY largemouth bass during only a single year (Garvey et al.2000). During that year, this effect occurred in four of the five reservoirs. Although not well understood, regional-scale climatic patterns (e.g., low precipitation and warm temperatures) affecting all of these systems similarly during spring probably allowed largemouth bass to hatch relatively early and consume gizzard shad before shad outgrew their size-dependent vulnerability (Garvey et al. 2000). Because the switch to piscivory depends on variable timing that is affected by both regional (e.g., climate) and local (e.g., watershed size) scale processes, first-year growth of largemouth bass varies tremendously both among systems and years (Garvey et al. 1998, 2000).

\section{Scale-dependent feedbacks among watersheds, gizzard shad, and reservoir food webs}

Feedbacks among gizzard shad life history, reservoirs, and watersheds most likely operate at various temporal and spatial scales, influencing the degree of gizzard shad dominance in reservoir ecosystems. Here we discuss some of these feedbacks and their potential role along the reservoir productivity gradient.

Gizzard shad population resilience: Feedbacks involving density-dependent diets and growth. Features of gizzard shad life history can elicit density-dependent feedbacks that facilitate population recovery following year-class failures. For example, gizzard shad biomass declined over an order of magnitude from 1994 to 1996 in Acton Lake following a couple of poor year classes (Schaus et al. 2002). When shad biomass declined in early summer 1996, Daphnia became abundant, and adult and juvenile gizzard shad consumed more zooplankton than usual. Given this nutritionally rich food source (compared to detritus), YOY gizzard shad grew more than twice as rapidly as detritivorous YOY fish from other years (Schaus et al.2002). This rapid growth quickly restored shad biomass, and also apparently caused Daphnia to decline to their usual low densities, at which point shad once again became almost entirely detritivorous. In addition, some shad born in 1996 reproduced in 1997 at age 1, which is earlier than usual. These density-dependent feedbacks increase the chance that gizzard shad will dominate fish biomass, even with periodic declines in reproduction and recruitment—especially in highly productive habitats.

\section{Gizzard shad and watersheds as sources of nutrients: Scale-} dependent feedbacks. The relative importance of gizzard shad and watersheds as nutrient sources varies with temporal scale, and involves a feedback between watershed degradation and shad biomass. The massive amounts of nutrients delivered in a single large storm can render nutrient transport by gizzard shad irrelevant for a period of a few days to a week (figure 6a). At longer time scales, however, increased inputs of nutrients and detritus from watersheds (e.g., resulting from increased watershed agriculture) will increase gizzard shad biomass, which will ultimately increase the rate at which gizzard shad provide nutrients to phytoplankton. Thus, watershed subsidies and gizzard shad may synergistically regulate reservoir productivity over long time scales (Vanni and Headworth 2004).

Feedbacks between turbidity, zooplankton population dynamics, and gizzard shad feeding behavior. The large input of sediments delivered by agricultural watersheds not only provides a potential food source for postlarval gizzard shad, but also increases water column turbidity and hence reduces light intensity. This may select against fish species that rely on vision for feeding. Thus, inorganic turbidity should favor dominance of gizzard shad, because the ability of visual predators to capture gizzard shad may be reduced at high turbidity, and because shad can consume sediment detritus without relying on vision. In addition, because high concentrations of suspended sediments interfere with the feeding of large zooplankton species, such as Daphnia, but not of smaller taxa such as rotifers, high sediment input from the watershed may promote dominance of small zooplankton (Kirk and Gilbert 1990). Dominance of small, selectively feeding zooplankton may also be favored by cyanobacteria-dominated phytoplankton assemblages (Gilbert 1990), which tend to occur more frequently in productive lakes. Thus, degradation of watersheds toward an agricultural landscape, by increasing 


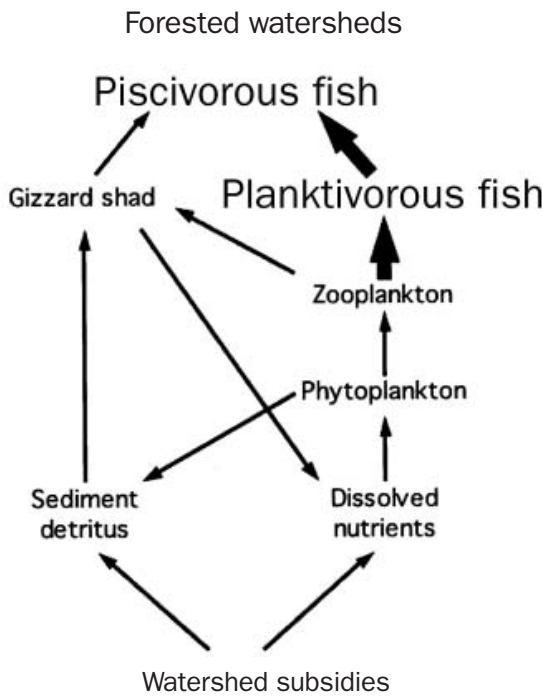

Reservoirs characterized by

- Low sediment input

- Low phytoplankton biomass

- High sport-fish abundance
Agricultural watersheds

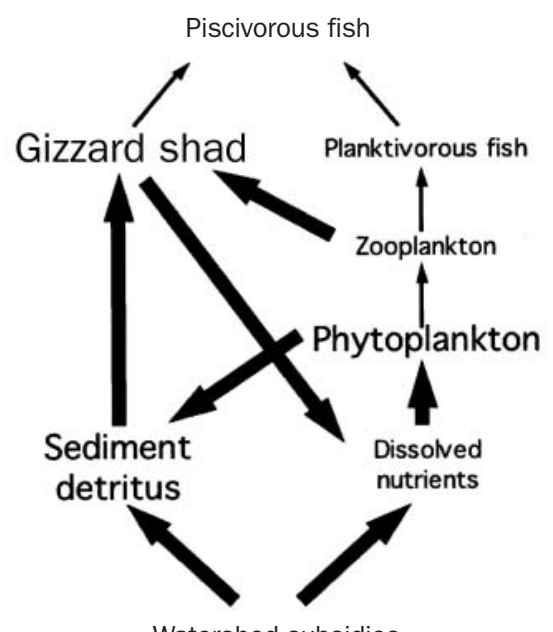

Watershed subsidies

Reservoirs characterized by

- High sediment input

- High phytoplankton biomass

- Low sport-fish abundance

Figure 7. Food-web interactions in reservoirs in forest-dominated and agriculturedominated watersheds (modified from Power et al. 2004). Forested watersheds have small nutrient and detritus subsidies from watersheds, leading to low abundance of phytoplankton and gizzard shad. Planktivorous fish thrive because of low shad abundance, leading to healthy populations of piscivorous fish. In agriculturedominated watersheds, nutrient and detritus subsidies are large, which stimulates productivity of phytoplankton and zooplankton, and provides increased detrital resources for gizzard shad. Gizzard shad biomass is high, leading to high rates of nutrient translocation from shad to phytoplankton. Dissolved nutrient (phosphorus) concentrations remain low because of phytoplankton uptake. High shad biomass leads to low abundance of planktivorous and piscivorous fish, because predation by larval and juvenile gizzard shad keeps zooplankton biomass at low levels, and because gizzard shad are not as vulnerable to piscivores as are planktivorous fish. Larger type and arrows indicate larger quantities and effects.

productivity and inorganic turbidity in reservoirs, favors dominance of gizzard shad and smaller zooplankton taxa.

Shifts toward small zooplankton can have at least two important feedbacks. First, the ability of gizzard shad to utilize small zooplankton better than other fish species, and the reliance of larval gizzard shad on small zooplankton, should further promote gizzard shad dominance. Second, a small-bodied zooplankton assemblage can result in low grazing pressure on phytoplankton, increasing the chance that phytoplankton biomass will increase in response to nutrient translocation by gizzard shad (Schaus and Vanni 2000).

\section{Feedbacks involving shifts between clear and turbid states.}

Some lakes, especially shallow ones, have been found to exhibit two alternate stable states. A clear state may exist, with low phytoplankton biomass and high biomass of vascular plants, which thrive under clear conditions. Alternatively, a turbid state may exist, with high concentrations of phytoplank- ton and suspended sediment and low abundance of vascular plants, which become light limited under turbid conditions (Scheffer and Carpenter 2003). A lake can switch abruptly between states, as a result of both external and internal forcing functions, including fish population dynamics (Scheffer et al. 2003). For example, omnivorous fish such as gizzard shad can help keep lakes in a turbid state because they facilitate phytoplankton productivity (via nutrient translocation and trophic cascades) and because their bioturbation of sediments may increase the likelihood that sediments are resuspended by wind (Scheffer et al. 2003). Thus, interactive effects of watersheds (via provision of nutrients and sediment) and gizzard shad may determine the probability of whether a reservoir exists in a clear or turbid state. However, because many reservoirs in Midwestern agricultural landscapes have such high turbidity, it is possible that even large reductions in gizzard shad abundance will not induce a clear state in these systems.

What limits gizzard shad abundance? The positive feedbacks presented above paint a picture of steadily increasing gizzard shad abundance as watersheds become degraded by agriculture. Thus, we must ask the question, What limits gizzard shad population size? Density dependence of gizzard shad growth and reproduction may play a role. DiCenzo and colleagues (1996) and Schaus and colleagues (2002) found that gizzard shad growth rates decreased when shad biomass was high, and other studies have found that shad in productive reservoirs (where population biomass is high) are dominated by smaller adults than those in less productive reservoirs (with low population biomass). Small size may result in decreased reproduction, thereby stabilizing biomass. In addition, smaller size may render gizzard shad more vulnerable to piscivores, thereby increasing the chance that piscivores will limit gizzard shad abundance.

The occurrence of periodic mass mortality events due to low temperatures and low oxygen (hypoxia) may also be important. Periods of hypoxia can occur under ice, or in summer if anoxic bottom waters mix with surface waters. Winterkills of gizzard shad are common, especially near the northern limit of their geographical distribution, and can be caused by low temperature or hypoxia. Hypoxia is more likely in highly productive lakes than in unproductive lakes because high algal biomass provides more substrate for bacteria, resulting in more oxygen depletion. Because gizzard shad 
can increase primary productivity, as discussed above, high shad biomass may ultimately increase the probability of hypoxia-induced mortality, thus setting in motion another feedback process. After winter- or summerkill, gizzard shad populations can typically rebound quickly for the reasons described above. The increased chances of winterkill and summerkill in productive reservoirs, along with the rapid recovery of shad populations following die-offs, suggest that interannual variability in shad recruitment and abundance should be highest in productive reservoirs.

\section{Management implications}

The interactions between watersheds and gizzard shad suggest that management of fisheries and water quality of reservoirs must proceed in tandem. Eutrophication remains the most pervasive water-quality problem in freshwater ecosystems (Carpenter et al. 1998). We contend that successful prevention, control, or reversal of eutrophication in reservoirs of eastern North America must consider both watershed inputs and gizzard shad abundance. The interactions between watersheds and gizzard shad also imply that some effects of watershed management may require relatively long time scales to be effective, but may result in relatively large effects. Thus, if watershed management results in decreased watershed subsidies to a productive reservoir, this may directly reduce phytoplankton productivity in a relatively short time period. Gizzard shad biomass should also decrease, but over a longer time scale, because shad can persist on sediment detritus that has accumulated in earlier years. The effectiveness of watershed management to reduce gizzard shad biomass may depend on the ability to reduce particulate nutrients, which may provide a detrital resource for shad. If so, management agencies should promote methods that reduce soil erosion from agricultural areas, such as conservation tillage and preservation of riparian areas.

In reservoirs with high inputs of nutrients from the watershed, control of gizzard shad by stocked exotic predators such as hybrid striped bass has been suggested as a management tool (Dettmers et al. 1996). If hybrid striped bass reduce gizzard shad densities, zooplankton abundances should increase, thereby facilitating growth and survival of other zooplanktivorous prey fish for predators such as age-0 largemouth bass. Because littoral largemouth bass and pelagic hybrid striped bass probably do not overlap spatially, we expect little direct interaction between them, suggesting that introductions of these exotic predators should not directly negatively affect native piscivores. Pond experiments showed that hybrid striped bass can reduce gizzard shad densities, allowing zooplankton to increase to levels that support bluegill recruitment (Dettmers et al. 1996). However, field experiments, surveys, and modeling suggest that control of gizzard shad by hybrid striped bass is limited to a relatively small subset of reservoirs in which stocking densities of hybrid striped bass are high, larval gizzard shad densities are low, and zooplankton productivity is high (Dettmers and Stein 1996, Dettmers et al. 1996). For example, only about $5 \%$ of reser- voirs in Ohio have this combination of characteristics (Dettmers et al. 1998), and this percentage is likely to be similar throughout the Midwestern United States. This greatly limits this management tactic in this region.

Reducing watershed inputs of nutrients to highly eutrophic reservoirs should favor economically important sportfish species, such as bluegill and largemouth bass, as gizzard shad biomass declines. Hence, traditional fishery management agencies that have historically focused on system-specific population dynamics of sport fish should begin to document watershed land use and form strong working relationships with land managers to improve fishery performance. The relationships among watersheds, gizzard shad population dynamics, and sport-fish assemblages suggest that management of largemouth bass and other native species may well be organized at the landscape (watershed) scale, which is also an appropriate scale for managing water quality. Systems receiving large nutrient inputs from watersheds may be candidates for stocking of exotic sport fish, such as hybrid striped bass, while management of naturally reproducing, native sport fish may be more successful in reservoirs with watersheds that yield lower levels of nutrients. Mechanisms underlying sport-fish recruitment and population dynamics are certainly complex. However, as researchers explore mechanisms across gradients of watershed land use and ecosystem productivity, generalities will continue to emerge, providing useful management insight.

\section{Beyond reservoirs: The generality of landscape-detritivore linkages}

Because gizzard shad are widely distributed and abundant, interactive effects of watersheds and gizzard shad are probably common, potentially affecting thousands of reservoir ecosystems across eastern North America. In these reservoirs, it appears that no other fish species can play the same role as gizzard shad. While a few other species consume detritus in these ecosystems, none attains the abundance of gizzard shad. Thus, it appears that gizzard shad are unique in their effects on reservoir ecosystems of eastern North America.

Are linkages between landscapes and detritivores or omnivores important in other ecosystems? Subsidies of detritivore populations through allochthonous inputs are apparently very common in aquatic and terrestrial ecosystems, and in some ecosystems subsidized detritivore populations can have far-reaching effects on their resident food webs (Moore et al. 2004, Polis et al. 2004). Although there are few detritivorous fish species in temperate fresh waters, there are numerous other detritivorous taxa in these ecosystems. For example, many stream invertebrates are largely subsidized by inputs of terrestrial leaf litter, and they in turn directly or indirectly affect other stream organisms, such as fish, other invertebrates, and algae (Wallace et al. 1999). Similarly, inputs of dissolved detritus (organic matter) from forested watersheds can drive food-web dynamics in northern temperate lakes (Pace et al. 2004). In addition, detritivory is common among marine fishes (especially in estuaries and coastal areas) and among 
tropical freshwater fishes. Interestingly, these ecosystems are also characterized by large inputs of allochthonous detritus. For example, floodplain lakes along large tropical rivers (the most common type of lake in many tropical areas) receive large inputs of sediment and other detritus from rivers, and support many species of detritivorous fish. Very little is known about the impacts of these detritivores on their resident ecosystems, but they are sufficiently abundant to be important food sources for local people (Lowe-McConnell 1987), suggesting that they may strongly interact with other members of local food webs. Large, low-gradient rivers and estuaries are perhaps most similar to reservoirs; they have large watersheds and receive pulses of nutrients and detritus in a manner similar to that of reservoirs. More generally, it is likely that detrital inputs have strong effects on many food webs, including effects that propagate to the more wellstudied "green-world" (i.e., plant-herbivore-based) foodweb channels (Moore et al. 2004). However, in comparison to our knowledge of top-down and bottom-up interactions in green-world food webs, we know relatively little about the dynamics of detritus and its impacts (Moore et al. 2004).

The interactive effects of watersheds and gizzard shad described here provide a framework for understanding and managing reservoir ecosystems. Although reservoirs are unique in that detritivorous gizzard shad can dominate fish biomass, the principles described here regarding interactive effects of landscapes, detritus, and key species may be widespread and common in other ecosystem types. Thus, the broad spatial framework afforded by a landscape perspective may greatly increase our ability to understand how food webs are regulated (Polis et al. 2004).

\section{Acknowledgments}

We are grateful to the National Science Foundation and the Ohio Department of Natural Resources, Division of Wildlife, for financial support to carry out research on reservoirs and their watersheds, and to three anonymous reviewers for comments on the manuscript. Finally, we thank the many students and technicians who have assisted with field and lab work associated with this research.

\section{References cited}

Adams SM, Kimmel BL, Ploskey GR. 1983. Sources of organic matter for reservoir fish production: A trophic-dynamics analysis. Canadian Journal of Fisheries and Aquatic Sciences 40: 1480-1495.

Aday DD, Hoxmeier RJH, Wahl DH. 2003. Direct and indirect effects of gizzard shad on bluegill growth and population size structure. Transactions of the American Fisheries Society 132: 47-56.

Allen MS, Greene JC, Snow FJ, Maceina MJ, DeVries DR. 1999. Recruitment of largemouth bass in Alabama reservoirs: Relations to trophic state and larval shad occurrence. North American Journal of Fisheries Management 19: 67-77.

Bachmann RW, Jones BL, Fox DD, Hoyer M, Bull LA, Canfield DE. 1996. Relations between trophic state indicators and fish in Florida (USA) lakes. Canadian Journal of Fisheries and Aquatic Sciences 53: 842-855.

Bremigan MT, Stein RA. 1994. Gape-dependent larval foraging and zooplankton size: Implications for fish recruitment across systems. Canadian Journal of Fisheries and Aquatic Sciences 51: 913-922.
1999. Larval gizzard shad success, juvenile effects, and reservoir productivity: Toward a framework for multi-system management. Transactions of the American Fisheries Society 128: 1106-1124.

-2001. Variable gizzard shad recruitment with reservoir productivity: Causes and implications for classifying systems. Ecological Applications 11: 1425-1437.

Bunnell DB, Gonzalez MJ, Stein RA. 2003. Zooplankton biomass enhances growth, but not survival, of first-feeding Pomoxis spp. larvae. Canadian Journal of Fisheries and Aquatic Sciences 60: 1314-1323.

Carpenter SR, Kitchell JF, Hodgson JR. 1985. Cascading trophic interactions and lake productivity. BioScience 35: 634-639.

Carpenter SR, Caraco NF, Correll DL, Howarth RW, Sharpley AN, Smith VH. 1998. Nonpoint pollution of surface waters with phosphorus and nitrogen. Ecological Applications 8: 559-568.

Dettmers JM, Stein RA. 1996. Quantifying linkages among gizzard shad, zooplankton, and phytoplankton in reservoirs. Transactions of the American Fisheries Society 125: 27-41.

Dettmers JM, DeVries DR, Stein RA. 1996. Quantifying responses to hybrid striped bass predation across multiple trophic levels: Implications for reservoir biomanipulation. Transactions of the American Fisheries Society 125: 491-504.

Dettmers JM, Stein RA, Lewis EM. 1998. Potential regulation of age-0 gizzard shad by hybrid striped bass in Ohio reservoirs. Transactions of the American Fisheries Society 127: 84-94.

DeVries DR, Stein RA. 1990. Manipulating shad to enhance sport fisheries in North America: An assessment. North American Journal of Fisheries Management 10: 209-223.

- 1992. Complex interactions between fish and zooplankton: Quantifying the role of an open-water planktivore. Canadian Journal of Fisheries and Aquatic Sciences 49: 1216-1227.

DiCenzo VJ, Maceina MJ, Stimpert MR. 1996. Relations between reservoir trophic state and gizzard shad population characteristics in Alabama reservoirs. North American Journal of Fisheries Management 16: 888-895.

Drenner RW, Mummert JR, Denoyelles F, Kettle D. 1984. Selective particle ingestion by a filter-feeding fish and its impact on phytoplankton community structure. Limnology and Oceanography 29: 941-948.

Drenner RW, Threlkeld ST, McCracken MD. 1986. Experimental analysis of the direct and indirect effects of an omnivorous filter-feeding clupeid on plankton community structure. Canadian Journal of Fisheries and Aquatic Sciences 43: 1935-1945.

Drenner RW, Smith JD, Threlkeld ST. 1996. Lake trophic state and the limnological effects of omnivorous fish. Hydrobiologia 319: 213-223.

Garvey JE, Stein RA. 1998a. Linking bluegill and gizzard shad prey assemblages to growth of age-0 largemouth bass in reservoirs. Transactions of the American Fisheries Society 127: 70-83.

- 1998b. Competition between larval fishes in reservoirs: The role of relative timing of appearance. Transactions of the American Fisheries Society 127: 1021-1039.

Garvey JE, Dingledine NA, Donovan NS, Stein RA. 1998. Exploring spatial and temporal variation within reservoir food webs: Predictions for fish assemblages. Ecological Applications 8: 104-120.

Garvey JE, Wright RA, Stein RA, Ferry KH. 2000. Evaluating how local- and regional-scale processes interact to regulate growth of age-0 largemouth bass. Transactions of the American Fisheries Society 129: 1044-1059.

Gilbert JJ. 1990. Differential effects of Anabaena affinis on cladocerans and rotifers: Mechanisms and implications. Ecology 71: 1727-1740.

Kirk KL, Gilbert JJ. 1990. Suspended clay and the population dynamics of planktonic rotifers and cladocerans. Ecology 71: 1741-1755.

Knoll LB, Vanni MJ, Renwick WH. 2003. Phytoplankton primary production and photosynthetic parameters in reservoirs along a gradient of watershed land use. Limnology and Oceanography 48: 608-617.

Lowe-McConnell RH. 1987. Ecological Studies in Tropical Fish Communities. New York: Cambridge University Press.

Michaletz PH. 1997. Factors affecting abundance, growth, and survival of age-0 gizzard shad. Transactions of the American Fisheries Society 126: 84-100. 
Miranda LE. 1983. Average ichthyomass in Texas large impoundments. Proceedings of the Texas Chapter of the American Fisheries Society 6: 58-67.

Miranda LE, Gu H. 1998. Dietary shifts of a dominant reservoir planktivore during early life stages. Hydrobiologia 377: 73-83.

Moore JC, et al. 2004. Detritus, trophic dynamics and biodiversity. Ecology Letters 7: 584-600.

Mundahl ND, Wissing TE. 1987. Nutritional importance of detritivory in the growth and condition of gizzard shad in an Ohio reservoir. Environmental Biology of Fishes 20: 129-142.

Osborne LL, Wiley MJ. 1988. Empirical relationships between land use/cover and stream water quality in an agricultural watershed. Journal of Environmental Management 26: 9-27.

Pace ML, Cole JJ, Carpenter SR, Kitchell JF, Hodgson JR, Van de Bogart MC, Bade DL, Kritzberg ES, Bastviken D. 2004. Whole-lake carbon-13 additions reveal terrestrial support of aquatic food webs. Nature 427: 240-243.

Page LM, Burr BM. 1991. A Field Guide to Freshwater Fishes: North America North of Mexico. Boston: Houghton Mifflin.

Polis GA, Myers CA, Holt RD. 1989. The ecology and evolution of intraguild predation: Potential competitors that eat each other. Annual Review of Ecology and Systematics 20: 297-330.

Polis GA, Power ME, Huxel GR, eds. 2004. Food Webs at the Landscape Level. Chicago: University of Chicago Press.

Pollard AI, Gonzalez MJ, Vanni MJ, Headworth JL. 1998. Effects of turbidity and biotic factors on the rotifer community in an Ohio reservoir. Hydrobiologia 388: 215-223.

Power ME, Vanni MJ, Stapp PT, Polis GA. 2004. Subsidy effects on managed ecosystems: Implications for sustainable harvest, conservation, and control. Pages 387-409 in Polis GA, Power ME, Huxel GR, eds. Food Webs at the Landscape Level. Chicago: University of Chicago Press.

Puckett LJ. 1995. Identifying the major sources of nutrient water pollution. Environmental Science and Technology 29: A408-A414.

Schaus MH, Vanni MJ. 2000. Effects of gizzard shad on phytoplankton and nutrient dynamics: Role of sediment feeding and fish size. Ecology 81: 1701-1719.
Schaus MH, Vanni MJ, Wissing TE, Bremigan MT, Garvey JE, Stein RA. 1997. Nitrogen and phosphorus excretion by detritivorous gizzard shad in a reservoir ecosystem. Limnology and Oceanography 42: 1386-1397.

Schaus MH, Vanni MJ, Wissing TE. 2002. Biomass-dependent diet shifts in omnivorous gizzard shad: Implications for growth, food web, and ecosystem effects. Transactions of the American Fisheries Society 131: 40-54.

Scheffer M, Carpenter SR. 2003. Catastrophic regime shifts in ecosystems: Linking theory to observation. Trends in Ecology and Evolution 18: 648-656.

Scheffer M, Portielje R, Zambrano L. 2003. Fish facilitate wave resuspension of sediment. Limnology and Oceanography 48: 1920-1926.

Soranno PA, Hubler SL, Carpenter SR, Lathrop RC. 1996. Phosphorus loads to surface waters: A simple model to account for spatial pattern of land use. Ecological Applications 6: 865-878.

Stein RA, DeVries DR, Dettmers JM. 1995. Food-web regulation by a planktivore: Exploring the generality of the trophic cascade hypothesis. Canadian Journal of Fisheries and Aquatic Sciences 52: 2518-2526.

Thornton KW. 1990. Perspectives on reservoir limnology. Pages 1-14 in Thornton KW, Kimmel BL, Payne FE, eds. Reservoir Limnology: Ecological Perspectives. New York: John Wiley and Sons.

Vanni MJ, Headworth JL. 2004. Cross-habitat transport of nutrients by omnivorous fish along a productivity gradient: Integrating watersheds and reservoir food webs. Pages 43-61 in Polis GA, Power ME, Huxel GR, eds. Food Webs at the Landscape Level. Chicago: University of Chicago Press.

Vanni MJ, Renwick WH, Headworth JL, Auch JD, Schaus MH. 2001. Dissolved and particulate nutrient flux from three adjacent agricultural watersheds: A five-year study. Biogeochemistry 54: 85-114.

Wallace JB, Eggert SL, Meyer JL, Webster JR. 1999. Effects of resource limitation on a detrital-based ecosystem. Ecological Monographs 69: 409-442.

Watson DL, Bayne DR, DeVries DR, Williams J. 2003. Influence of gizzard shad on phytoplankton size and primary productivity in mesocosms and earthen ponds in the southeastern U.S. Hydrobiologia 495: 17-32.

Williamson CE. 1980. The predatory behavior of Mesocyclops edax: Predator preferences, prey defenses, and starvation-induced changes. Limnology and Oceanography 25: 903-909.

\section{$\Phi \Sigma$ \\ Phi Sigma \\ $\Phi \Sigma$}

\section{The Academic Honor Society for the Biological Sciences}

- established in 1915 for the recognition of academic excellence and research in the biological sciences

- member of the American Institute of Biological Sciences (AIBS)

- member of the Association of College Honor Societies (ACHS)

- affiliate of the American Association for the Advancement of Science (AAAS)

For more information, contact: Henry R. Owen, Ph.D.

President of Phi Sigma Honor Society

Department of Biological Sciences

Eastern Illinois University

Charleston, IL 61920 USA

or visit our web site at:

www.phisigmasociety.org 